\title{
BIOMASS LOSS AS AN INDEX OF POLLUTION IN VARIOUS GRADIENT OF A CRUDE OIL POLLUTED TERRESTRIAL ENVIRONMENT.
}

\author{
N. L. EDWIN-WOSU and P. D. S. KINAKO \\ (Received 7 April, 2004; Revision Accepted 9 July, 20()t)
}

\begin{abstract}
Bauhinia monandra is an agroforestry species in the FABACEAE plant family, an exotic species from Burma, 'easily available and accessible for ornamental and agro-forestry purposes, and more so abundantly distributed in tropical countries including oil producing areas in Nigeria. Its sensitivity to crude oil pollution has been evaluated under controlled condition. At the various levels of pollution B.monandra was very susceptible to the crude oil pollution. The magnitude of the impact for aerial biomass in the light medium \& heavy intensities show a reduction of about $92 \%$, $93 \% \& 94 \%$, respectively. $98.1 \%, 98.3 \%$ and $99.1 \%$ were recorded for underground biomass loss, respectively, while $95.0 \% 95.1 \%$ and $96.4 \%$ for total biomass were recorded, respectively, after the period of growth. With its susceptibility at a very low intensity, B.monandra could be a bioindicator for oil pollution in terrestrial environment.
\end{abstract}

KEY WORDS:"Bauhinia monandra, crude oil, biomass, terrestrial environment, ecotoxicity.

\section{INTRODUCTION}

There have been several cases of oil pollution in our environment. These pose serious threai to both terrestrial and aquatic habitats. Series of work have revealed that cil pollutant has some effects on the biomass accumulation of macrophytes. Terrestrial macrophytes are important links in food chain and biogeochemical and energy cycling in the terrestrial habitat. They are the first victims of oil spill on land ecosystem. Oil may kill a plant or inhibit the growth of vegetation that is already established (Cook \& Westlake, 1977).

Oil readily penetrates the pore spaces of terrestrial vegetation on landing following any spill. Bossert and Bartha (1984) report that hydrocarbons penetrate the plant tissue easily. This prevents the effective translocation of vital mineral salts between the root and the shoot system. This is usually demonstrated by a darkening of the leaf as its air-spaces become filled with oil; Heavier fractions may block them up, while the coating of dark oil excludes the sunlight necessary for the functioning of all green plants. This subsequently impedes photosynthetic activity. It is further reported that oil penetrates the leaves of plants and interferes with their physiological functioning such as photosynthesis and biomass accumulation (Odu 1977 \& 81). Information on the biomass response of macrophytes to crude oil pollution could serve as an indicator for a possible risk the Bauhinia monandra plant could be exposed to when there is a spill incident. Bauhinia monandra is of the FABACEAE plant family, a native of Burma, but was introduced into Nigeria and have naturalized. It is easily available and accessible for ornamental and agro-forestry purposes. The aim of this study was to investigate the ecotoxicological effects of different intensities of crude oil pollution on the Biomass accumulation of Bauhinia monandra.

\section{MATERIALS AND METHODS}

The crude oil used for this study was obtained from the Shell Petroleum Development Coinpany (SPDC), Port Harcourt. The plant species B.monandra was obtained from the social science quadrangle, Uniport. Polybags which were used as growth chambers, were obtained from the Rivers State Agricultural Development Programme (ADP).

Crude oil sensitivity study: studies on the effects of crude oil pollution were carried out in 40 polybags, each having a surface area of $78.5 \mathrm{~cm}^{2}$. Each of these bags was filled with $1.4 \mathrm{~kg}$ of loam soil. The pollution was in doses by measuring cylinder of $25 \mathrm{ml}$, $50 \mathrm{ml} 100 \mathrm{ml}$ and control, and each dose replicated 10 times. The plant species was planted into control and polluted soils in the polybags. Growth performance was monitored for 16 weeks, at the end of which biomass analysis was carried out after harvesting

Determination of plant biomass: The weight of the plant was determined in two phases (the wet weight and dry weight) at the end of the study. The wet weight was obtained using mettler PN 163 scale. The plant parts of known fresh weight were then wrapped in an alluminum foil and placed in an oven set at $10^{\circ} \mathrm{C}$ for 8 days. The dried plants were weighed again to obtain the dry weight of the plant.

\section{RESULTS AND DISCUSSION}

The plant biomass comprises the dry matter yield for the above ground and belowground biomass at the end of the study. The response in terms of biomass accumulation in the polluted habitat of the B.monand.a is presented in Figure 1. The response and tolerance of the plant species were in relation to various levels of pollution intensity. The pollution reduced the dry matter
yields of Bauhinia monandra. 


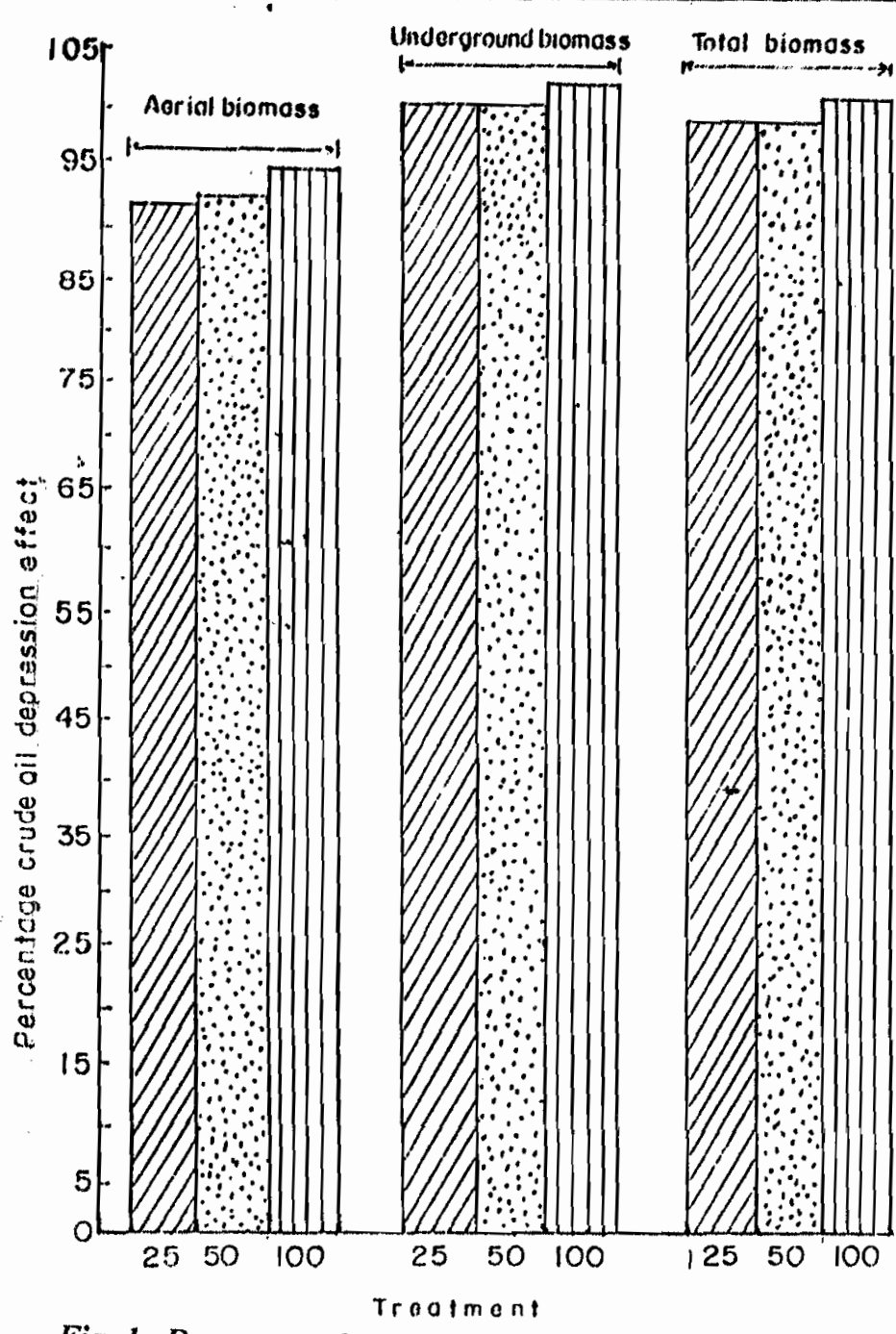

Fig. 1: Percentage depression of the biomass of Bauhing monandra grown in various levels of crude oil polluted. llos wDO

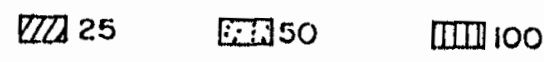

Bauhinia monandra at the various pollution levels (light, medium \& heavy) had aboveground biomass $(g)$ of $0.09 \pm 0.03,0.08 \pm 0.04$, and $0.07 \pm 0.04$, with depression effect of $92 \%, 93 \%$ and $94 \%$ respectively. Below ground biomass $(g)$ was $0.021 \pm 0.03,0.019 \pm 0.03$ and $0.01 \pm 0.00$ and crude oil depression of $98.1 \%, 98.3 \%$ and $99.1 \%$. Ezeala (1987) has observed $80 \%$ loss in biomass productivity of Pistia stratiotes following crude oil effect.
While the total biomass $(g)$ of Bauhinia monandra at the various pollution was $0.11 \pm 0.04,0.11 \pm 0.04$ and $0.08 \pm 0.04$, with a depression of $95.0 \%, 95.1 \% \& 96.4 \%$, respectively. The control had such dry matter yield as $1.11 \pm 0.44,1.11 \pm 0.21$ and $2.22 \pm 0.41$ for above and belowground and total biomass, respectively (seeTable 1).

Further studies have shown that the observed reduction in biomass production could be attributed to abnormalities induced by the oil pollution in the physical and physiological activities of the plant. Odu (1977 \& 81) has reported that oil, on landing on the leaves of plant. penetrates the leaves and interferes with the physiological functioning. The oil pollution which was observed to have affected the photosynthetic activities of the plant will equally affect the plant productivity, thus a reduction in total biomass observed. Kinako (1981) also observed $74 \%$ reduction in biomass productivity of a simple grass-herb in an oil polluted terrestrial ecosystem. Similar results were reported by Currier and Peoples (1954), Baker (1970) and Amakiri

and Onofeghara (1983) on different plants and at different conditions. The biomass loss in Bauhinia monandra caused by crude oil pollution could be explained as observed by Baker (1970) and suggested by Amakiri and Onofeghara (1983) that the crude oil could enter into the intercellular spaces and interfere with water and nutrient uptake and gaseous exchange of the cells. Such condition could result in a situation of physiological drought and gradual suffocation.

\section{CONCLUSION}

In conclusion, the results presented in this paper have shown that B.monandra is exiremely sensitive to very light crude oil pollution. The plant can serve as a sensitivity index for oil pollution particularly in areas like the Niger Delta of Nigeria where oil exploration is carried out intensively. For a holistic understanding of the abnormal ecophysiological implication of this pollutant on the plant, there is need to unveil the effect of this oil on the molecular level, which could be another trend of investigation for biomass study.

\section{REFERENCES}

Amakiri, J. O. and Onofeghara, F. A., 1983. Effect of crude oil pollution on the growth of "Zea mays, Abelmoschus esculentus and Capsicum frutescence" oil and petrochemical, pollution 1:199-205

Table 1: The mean \pm standard deviation and \% depression of Above-ground, underground and total plant biomass of Bauhinia monandra grown in the various leveis of crude oil polluted loam soil.

$\begin{array}{llll}\begin{array}{l}\text { Species } \\ \text { Parameter }\end{array} & \text { Above-ground biomass }(g) & \text { Under-ground biomass }(g) & \text { Total biom } \\ \text { Treatment (mill) } & & & \\ \text { Control } & 1.11 \pm 0.44 & 1.11 \pm 0.21 & 2.22 \pm 0.41 \\ 25 & 0.09 \pm 0.03 & 0.02 \pm 0.03 & 0.11 \pm 0.04 \\ 50 & 0.08 \pm 0.04 & 0.02 \pm 0.03 & 0.11 \pm 0.04 \\ 100 & 0.07 \pm 0.04 & 0.01 \pm 0.00 & 0.08 \pm 0.04\end{array}$


Baker, J. M., 1970. The effect of oil on plants. Environmental pollution 1:27-44.

Bossert, I. and Bartha, R., 1984. The fate of petroleum in soil ecosystems. pp. 435-479. In: petroleum Microbiology. Atlas, R. M Ed, Macmilları New York.

Cook, F. D. and Westlake, D. W. S., 1974. Microbial degradation of Northern crude oils, Environmental-social program, Northern Pipelines Task force, Report, 74 -1.

Currier, H. B and Peoples, S. A., 1954. Phytotoxicity of hydroçarbons. Hilgardia 23:155-173.

Ezeala, D. O., 1987. The sensitivity of Pistia stratiotes (A fresh water plant) to crude oil pollution pp 194196 Uniport, Port Harcourt.
Kinako, P. D. S., 1981. Short term effect of oil pollution on species number and productivity of a simple terrestrial ecosystem. Environ. Pollution (series A) 26: 87-91.

Odu, C. T. I., 1977 Oil polfution and the environment. Bull of Sci. Associ. Of Nigeria. 3 (21): 23-29

Odu, C. T. I., 1981. Degradation and Weathering of crude oil under tropical condition. In: The Petroluem Industry and the Nigeria Environment, proceedings of an international seminar. NNPC Nov 9-12. 1981. PTI. Warri, Nigeria, pp. 164-170. 